\title{
Digital Communication Tools: E-Wom in the Tourism \& Hospitality Industry
}

\section{Giuseppe Granata}

\author{
Department of Economics / University Mercatorum, Italy.
}

\begin{abstract}
The tourism industry has been greatly influenced by the development of information and communication technologies (ICT), as in the case of word-of-mouth digital communication or e-WOM, that allows users to express opinions about their experience as tourists online. Hotels are the providers of tourist services that are most interested in this communication tool, using which they can obtain feedback and information useful for improving management and economic results. To date, academic literature on this topic has been focused on consumers, and the research contribution related to management is limited. This research contributes to the study of e-WOM as a digital communication tool for hotels in the Italian context. A descriptive analysis of this phenomenon was carried out using a survey conducted among hotel managers and marketing managers. This survey revealed different points of view on different user profiles and hotels involved.
\end{abstract}

Keywords: Digital communication, E-WOM, Hotel industry, Relationship marketing, Word-of-mouth.

\section{INTRODUCTION}

The tourism industry is experiencing continuous growth. The flows of international tourists on a global scale increased from 674 million in 2000 to 1.4 billion in 2018 . Similarly, international tourism revenues generated by destinations around the world increased from $\$ 495,000$ million in 2000 to $\$$ $1,700,000$ million in 2018 (World Tourism Organization, UNWTO, 2019).

Italy and its regional destinations are among the most visited places in the world, and Italy is the fourth most visited international tourist destination (UNWTO, 2019). In terms of hotel services, Italy is the largest market in Europe and the third largest in the world after the United States and China, with more than a million rooms.

This market is quite fragmented (over 33,000 hotels) and is strongly influenced by a small independent hotel industry. The average throughput of hotels included in the list of chain-branded hotels is four times higher than that of independent ones, although the presence of chains in Italy is declining (EUROSTAT, 2016).
Worldwide, the global hotel offer remained almost constant: $-0.5 \%$ in 2012 and $-0.3 \%$ in 2013 , while hotel chains increased: $+3.4 \%$ in $2012,+1.6 \%$ in 2013 . Despite the above data, the Italian hotel industry is losing ground in terms of customer satisfaction, mainly due to the low perceived quality of the accommodation. It also loses competitiveness in the dynamism of international markets due to greater competitiveness in terms of the price of international competitors (Trademark, 2012).

\section{Italian Hotel Services}

Hotels in Italy classified in five categories based on the number of stars and hoteltourist residences (RTA) registered more than 263 million presences in 2014; an increase to almost 429 million in 2018. Even the total arrivals of tourists, whether resident or non-resident in Italy, show an important increase compared to previous years. In the case of high category hotels and hotel-tourist residences (RTA), attendance increases (4 and 5 stars), while the data show a decrease for 1 and 2-star hotels. 
Compared with the number of hotels available during the analyzed period, a significant reduction can be observed starting from 2012, when in 2015 there were approximately 530 objects less. Consequently, the number of places between 2012 and 2014 also decreases, reaching the levels of 2012 in the year 2015. The 2008 is the year of upward trend reversal with a slow and gradual reduction in the number of hotels. Data for 2008 show that 700 of the 34,000 existing structures were closed.

The low category hotels are the hardest hit (32.6\% less since 2004). On the other hand, luxury and high-class facilities increased by $61.7 \%$ (from $10.9 \%$ in 2004 to $17.8 \%$ of the total in 2014). In the period from 2004 to 2014, the number of rooms increased by 7.8\%. After a strong acceleration between 2004 and 2010, growth rates gradually decreased to 1.1 million (ISTAT, 2015). Thus, the Italian hotel market is currently dominated by the medium-high and luxury categories, representing approximately half of the total offer.

\section{Digital COMMUNICATION AND E-WOM IN THE HOTEL INDUSTRY}

The application of digital communication has been recognized as one of the main determinants of change in the hotel industry [1]. The motivation is based on the predominance of users authorized to define, customize and purchase travel services, as well as contribute to the globalization of the industry with the right tools to develop, manage and disseminate offers around the world [2]. Many hotels have resorted to digital technology to cope with an environment characterized by globalization, competition and rising expectations of guests. In the hotel industry, digital investment is significant, but does not always guarantee the expected return [3].

Among the various technological applications, there is an e-WOM that allows travellers to share their travel experiences [4], thereby influencing other people's purchasing decisions [5,6]. Del Chiappa [7] notes that after reading comments on the Internet, Italian tourists sometimes change hotels $(64.8 \%)$, almost always $(12 \%)$ or always (0.5\%). E-WOM also influences the decision to change the accommodation proposed by the travel agency [8], and has the advantage of offering solutions or identifying any errors related to the most important aspects on the client's perception side, which, in fact, contribute to most complaints $[9,1]$. In some cases, hotels cite the opinions of online customers as specific elements of the quality management of their offer [10]. Thus, hotels can use e-WOM to improve their competitiveness [2], positioning themselves in the minds of consumers through strategic and operational marketing, but not intrusive one [11].

However, the phenomenon did not have the same effects in all countries. In this regard, according to the "Connection Indicator System" (2015), Italy is in $22^{\text {nd }}$ place among 25 industrialized countries. Only 6 of the 18 million Italian yachtsmen seeking information and comparing products and offered services buy them online. In fact, 6.5 million euros represent $1 \%$ of total consumer sales with a large difference compared to the rest of Europe, where the value for B2C is on average 4\% (Eurostat 2016).

The limited use of e-commerce in Italy should also be noted, given that in $201671 \%$ of people made online purchases at least once, while in Germany this indicator was $91.0 \%$, in France this indicator were $88 \%$, and $83 \%$ in the UK. The reasons for such difference are Italy's structural constraints (Internet and broadband access, high logistics and distribution costs) and some of Italy's still limited attitudes, such as limited trust in online credit card payments (www.connectivityscorecard.org).

From a research point of view, most research on the use of information technology and ecommerce in the tourism industry focused on analyzing the consumer point of view [12-15], paying less attention to the proposed point of view.

This aspect could hide a limited interest on the part of management in the use $[16,17]$ and in the management of technological applications for the implementation of Business Development Strategies [18]. For this reason, the management of the impact of $\mathrm{e}-\mathrm{WOM}$ is a research field to be developed $[19,20]$. The present research aims to describe the condition of the e-WOM as a communication tool, the profile of the managers who use it, the reasons of its use 
and the benefit it provides to management [12].

\section{ReseARCH Methodology}

Using Google Forms, a questionnaire was developed for those who responsible for strategic decision-making in hotels. Since the sample was difficult to access, it was decided to follow the snowball sampling technique [21]. In the Italian context, 33.000 hotels of all categories are represented, although the considered number consists of hotels with available e-mail, a total of 500 (Table 1).

The questionnaire consists of questions aimed at studying the reasons for accepting and using e-WOM for management, the characteristics of e-WOM information, its benefits, intentions for future behavior, as well as the identification data of the respondent and his/her hotel. All variable opinions are measured on a 5-point Likert scale, from 1 "strongly disagree" to 5 "strongly agree" with the statement [22].

Table 1: Technical details of the survey

\begin{tabular}{|l|l|}
\hline Territory & 33,000 hotels in Italy \\
\hline Number of contact persons & 500 hotels via email \\
\hline Collection method and terms & Self-managed questionnaire, October - December \\
& 2018 \\
\hline Sampling procedure & Questionnaire sent to 100\% of the sample \\
\hline Sample Response Size & 105 questionnaires, all valid, 21\% response rate \\
\hline
\end{tabular}

\section{RESULTS}

The male response was $69.5 \%$, the female response was $30.5 \%$. The main age range of the sample is from 31 to 45 years (59.3\%) and from 46 to 60 years (22\%). Most participants play a strategic role in the organization (owner, director or manager), have a higher or secondary education (almost $70 \%$ have a high school diploma as the highest degree) and more than $80 \%$ of hotels have from 0 to 10 employees. $44.1 \%$ of respondents belong to 3-star hotels, followed by 4-star hotels (35.6\%). $62.7 \%$ of the sample belongs to the chain, and the remaining $37.3 \%$ are independent hotels.

Descriptive analysis begins with basic statistics of the mean and standard deviation and ends with the results of the T-test of the difference in means for the variables that are considered to be the key ones. For higher averages, respondents are considering using digital communications and e-WOM to achieve better results in customer satisfaction, interaction with them and the acquisition of new customers. It underlines the interest in implementing active and relational marketing using social tools. In addition, the claim that e-WOM offers benefits for the company has the highest average and a slight deviation.
According to the academic literature, the intention to continue considering e-WOM in the context of digital communication to make management decisions has the highest average (4.98 vs. 3.12 and 3.0). The quality of the information and the impact that they can have on managerial decisions in obtaining further thoughts and benefits are of rather low value, even if the reliability of the EWOM and its ability to accurately reflect reality have high values.

An analysis of the global reasons for accepting the use (attitude, subjective norms, and intended control) shows that this use is approved by an organization that is aware of the resulting management improvement. However, it seems that there is no broad consensus on aptitude for use.

Compared to the category, low level hotels less appreciates the e-WOM support to improve current products / services (average 2.67 vs 3.27). As for the other variables, low category hotels have lower average value with very significant differences regarding the benefit of the e-WOM information for decision-making than high category hotels. In the base of ownership, there is no material difference. In the base of the level of 
research, significant differences were found showing that respondents with higher education expressed more favourable opinions. In the base of the position of the respondent (owner vs. director), there are significant differences in the general reasons for acceptance in almost all subjects with higher average rates for directors than for hotel owners.

\section{CONCLUSION \\ AND MANAGERIAL IMPLICATIONS}

The analysis allows us to identify aspects related to the achievement of external quality (acquiring new customers, direct interaction, satisfaction, etc.), significantly improved through the use of digital communications and, in particular, through the use of eWOM. The characteristics of the position occupied in the hotel, the level of education of the decision maker and the category of the hotel as determinants of the differences observed among the interviewees were also identified.

Managers with a university degree and a specific director role in four- and five-star hotels have confidence in the positive role provided by e-WOM information, when there is an intention to improve management by implementing actions that increase the value of offer. On the other hand, in Italy, we note insufficient participation in the industry regarding the implementation of e-WOM, and this may represent a loss of competitiveness in the context of activities related to the perception of a decline in the quality of offered services.

Therefore, hotel managers are interested in using digital communication to advertise their services, and they need to build an interactive relationship with users to maintain active dialogues with them.

Finally, it was very interesting for managers to follow carefully the opinions expressed by users (through e-WOM) on their companies, to the point of being considered as influencers of some managerial choices. This research describes the situation through a sample of convenience. It would be desirable to continue the research on the basis of a wider and more balanced sample by analyzing additional aspects and constructing a theoretical model.

\section{REFERENCES}

1. Levy SE, Duan W, Boo S (2013) An Analysis of One-Star Online Reviews and Responses in the Washington, D.C., Lodging Market”, Cornell Hospitality Quarterly 54(1):49-63.

2. Buhalis D, Law R (2008) Progress in tourism management: twenty years on and 10 years after the internet: the state of eTourism research, Tourism Management, 29(4):609-623.

3. Cohen JF, Olsen K (2013) The impacts of complementary information technology resources on the service-profit chain and competitive performance of South African hospitality firms, International Journal of Hospitality Management, 34:245-254.

4. Bilgihan A, Barreda A, Okumus F, Nusair K (2016) Consumer perception of knowledge-sharing in travel-related online social networks, Tourism Management, 52:287-296.

5. Ayeh JK, Au N, Law R (2013) Do we believe in TripAdvisor? Examining credibility perceptions and online travelers' attitude toward using user generated content, Journal of Travel Research, 52:4.

6. Cheng VTP, Loi MK (2014) Handling negative online customer reviews: the effects of elaboration likelihood model and distributive justice, Journal of Travel \& Tourism Marketing, 31(1), 1-15.

7. Del Chiappa G (2011) Trustworthiness of Travel 2.0 applications and their influence on tourist behaviour: an empirical investigation in Italy. In Law, R., Fuchs, M e Ricci, F. (Eds). Information and Communication Technologies in Tourism 2011. Vienna, Springer.

8. Del Chiappa G (2013) Internet versus travel agencies: the perception of different groups of Italian online buyers, Journal of Vacation Marketing, 19:55-66.

9. Smyth B, Wu G, Greene D (2010) Does TripAdvisor makes hotels better? Technical Report (08):1-11.

10. Cobanoglu C, Berezina K, Kasavanac ML, Erdemd M (2011) The impact of technology amenities on hotel guest overall satisfaction, Journal of quality Assurance in Hospitality and Tourism 12(4):272-288. 
11. Gonzalez S, Aparici E (2008) Redes sociales. Una nueva interconexión entre marcas y personas, Harvard Deusto Marketing y Ventas 87:48-52.

12. Granata G, Scozzeze G (2018) The 18 Evolution of Virtual Marketing to improve Business Communication, International Business Research, vol. 11:12.

13. Vermeulen IE, Seegers D (2009) Tried and tested. The impact of online hotel reviews on consumer consideration, Tourism Management 30(1):123-127.

14. Jalilvand MR, Samiei N (2012), Examining the structural relationships of electronic word of mouth, destination image, tourist attitude toward destination and travel intention: An integrated approach, Journal of Destination Marketing and Management 1:134-143.

15. Ruiz ME, Gil I, Moliner B (2013) Las tecnologías que implantan los hoteles y las tecnologías que gustan a los huéspedes, Revista de Análisis Turístico 15(1):61-70.

16. Martinez J, Majo J, Casadesus M (2006) El uso de las tecnologías de la información en el sector hotelero. VI Congreso Turismo y Tecnologías de la Información y las Comunicaciones-Turitec, Málaga, p. 47-58.
17. Tsiotsou R, Ratten V (2010) Future research directions in tourism marketing, Marketing Intelligence and Planning 28(4): 533-544.

18. Law R, Jogaratnam G (2005) A study of hotel information technology applications. International Journal of Contemporary Hospitality Management 17(2):170-180.

19. Heung VCS (2003) Barriers to implementing E-commerce in the travel industry: a practical perspective, International Journal of Hospitality Management 22:111-118.

20. Cantallops SA, Salvi F (2014) New consumer behavior: A research on e-WOM and hotels, International Journal of Hospitality Management 36:41-51

21. Lopez M, Sicilia M (2013) Boca a boca tradicional versus electrónico: la participación como factor explicativo de la influencia del boca a boca electrónico, Revista Española de Investigación de Marketing - ESIC 17:7-38.

22. Likert $R$ (1932) A technique for the measurement of attitudes. Archives of Psychology, 140:1-50. (Traducción al castellano en C. H. Wainerman (Comp.) (1976), Escalas de medición en ciencias sociales, p-199-260. 